\title{
Microbial inactivation modeling and salting characteristics of shredded kimchi cabbages (Brassica pekinensis L.) treated with radio frequency heating
}

\author{
Eun Ji Choi, Hae Woong Park, Jung Gyu Lee, Ho Hyun Chun* \\ Advanced Process Technology and Fermentation Research Group, World Institute of Kimchi, Gwangju 61755, Korea
}

\section{라디오파 가열 처리한 절단 배추의 미생물 불활성 모델링 및 절임 특성}

\author{
최은지·박해웅·이중규·천호현* \\ 세계김치연구소 신공정발효연구단
}

\begin{abstract}
This study investigated the effect of radio frequency (RF) heating at 27.12 $\mathrm{MHz}$ on the inactivation of pre-existing microorganisms and salting characteristics of shredded kimchi cabbages. Samples of shredded kimchi cabbages were subjected to $27.12 \mathrm{MHz}$ RF heating at different power levels $(1,000$ and 1,500 W) or to hot water $(\mathrm{HW})$ at 60 and $70{ }^{\circ} \mathrm{C}$. RF heating at $1,500 \mathrm{~W}$ for $3 \mathrm{~min}$ reduced the populations of aerobic bacteria, yeast and molds, coliforms, and lactic acid bacteria in the shredded kimchi cabbage samples by $2.56,1.26,4.36$, and $4.31 \log \mathrm{CFU} / \mathrm{g}$, respectively; moreover, survival plots fitted using the Weibull model for $1,500 \mathrm{~W}$ RF heating yielded $D_{r}$ values of 1.92, 2.66, 1.81, and $0.75 \mathrm{~min}$, respectively. The salinity of shredded kimchi cabbages treated with RF and HW heating increased more rapidly than that of the control during salting. With respect to the moisture content and hardness in the shredded kimchi cabbages, no significant differences were observed among the treatments, after salting for $4 \mathrm{~h}$. In addition, the surface temperature distributions of the RF-heated samples were relatively uniform compared to those of the HW-heated samples. These results clearly indicated that the RF heating technology has the potential to decontaminate kimchi cabbages of pre-existing microorganisms, before the salting process.
\end{abstract}

Key words : shredded kimchi cabbage, radio frequency, microbial inactivation, salting, quality

서 론

김치는 한국인 식생활에서 가장 중요한 위치를 차지하는 부식이다(1). 2016년 국민영양통계에 따르면 김치는 국내 다소비 식품 중 3 순위로서 국민 1 인당 1 일 섭취량이 약 $62.4 \mathrm{~g}$ 이다. 최근에는 맞벌이 가구와 단체급식 증가, 가공식 품산업의 발달로 식생활 소비환경이 변화함에 따라 산업적 으로 대량 생산되는 상품 김치를 구매하거나 절임배추 상품

*Corresponding author. E-mail : hhchun@wikim.re.kr Phone : 82-62-610-1761, Fax : 82-62-610-1850

Received 18 September 2018; Revised 5 November 2018; Accepted 7 November 2018.

Copyright (c) The Korean Society of Food Preservation. All rights reserved.
을 준비하여 김치를 담그는 가정이 늘어나고 있다(2).

특히 배추김치의 주원료인 절임배추는 밭에서 수확한 배추를 정선 후 절단, 염수 절임, 세척 및 탈수를 거쳐 비가 열 제조되는데 토양 미생물과 병원성 미생물을 제거하는 공정이 절임배추의 위생과 품질 표준화에 결정적인 영향을 미친다(3). 절임배추 상품을 제조하는 김치가공업체들은 절임배추 구매 후 세척 없이 이용하는 방법을 권고하고 있으며 실제 대부분 소비자들도 구매한 절임배추를 세척하 지 않고 바로 이용하는 경우가 많아 위생적인 절임배추 생산에 대한 요구가 높다. 그러나 김치가공업체나 배추 산 지 작목반에서 관행적으로 이용하는 절임 후 수돗물 세척방 법은 절임배추에 존재하는 초기 미생물을 감소시키는데 효과적이지 못하다(4). 현재 국내에서 유통 중인 절임배추 의 미생물 오염도는 호기성 세균 수 4.7-7.1 $\log \mathrm{CFU} / \mathrm{g}$, 대장 균군 2.1-4.4 $\log \mathrm{CFU} / \mathrm{g}$, 유산균 3.6-6.7 $\log \mathrm{CFU} / \mathrm{g}$ 과 Bacillus 
cereus 1.0-2.0 $\log \mathrm{CFU} / \mathrm{g}$ 수준을 나타내고 있다(5,6).

지금까지 절임배추에 미생물 오염원을 감소시키기 위한 방법으로 절임 후 세척 단계에서 오존(7), 전해수(8) 또는 염소계 화합물(9) 등 화학적 살균제를 이용한 연구가 수행 된바 있지만 이취 발생, 작업자의 건강 유해 등 문제점이 발생할 우려가 있다. 특히 염소계 살균제는 식품 중 유기물 과 반응하여 클로로페놀이나 트리할로메탄을 생성하고 잔 류염소 때문에 실제 절임배추 가공현장에서 이용하기가 쉽지 않다(10). 따라서 절임배추의 미생물학적 안전성 확보 를 위해 제조 공정 중 효과적인 미생물 제어 기술 적용이 반드시 필요하다.

채소 가공 중 가열 전처리는 shelf-life 연장을 위한 전략으 로 이용되어져 왔다(11). 특히 저온 가열 살균은 채소의 미생물학적 안전성 확보와 효소 산화 불활성에 의한 품질 유지를 목적으로 하는 가장 보편적인 가열기술이다(12). 최근에는 라디오파 유전 가열(radio frequency dielectric heating) 기술을 이용한 급속 저온 가열 살균에 관심이 증대 되고 있다(13). 관행적인 저온 가열은 $60-90^{\circ} \mathrm{C}$ 열풍이나 열 수를 이용하여 열전달과 열확산으로 채소 조직표면에 미생 물을 살균시킨다(14). 반면 라디오파를 이용한 식품 가열의 원리는 전기장이 양과 음으로 진동할 때 식품 내부에 극성 을 가지는 물분자가 회전하고 충돌하며 발생되는 운동 및 마찰에너지가 열에너지로 바뀌면서 식품의 온도를 높이는 것이다(15). $13.56,27.12$ 와 $40.68 \mathrm{MHz}$ 라디오파 가열은 915 또는 $2,450 \mathrm{MHz}$ 마이크로파와 비교하여 식품에 침투깊이 가 높아 식품 내부 가열이 균일한 장점이 있다(16).

국외에서는 라디오파 에너지를 이용한 식품 가열 살균 연구가 활발히 수행되고 있다. 2018년 Kou 등(17)은 27.12 $\mathrm{MHz}$ 라디오파 처리에 따른 사과 주스와 으깬 감자에 접종 된 Escherichia coli와 Staphylococcus aureus 감소 효과를 보고하였다. 2017년 Geveke 등(15)은 라디오파 가열과 열수 병합처리가 열수 단독처리와 비교하여 계란 저온살균에 소요되는 시간을 약 $60 \%$ 감소한다는 결과를 발표하였다. 국내에서는 라디오파 가열 살균 연구 관련하여 아몬드, 고 춧가루 또는 후추에 인위적으로 오염시킨 Salmonella typhimurium, E. coli $\mathrm{O} 157: \mathrm{H} 7$ 등 병원성 미생물 감소 효과가 보고된 바 있다(18-20). 그러나 신선 배추에 오염미생물 불 활성을 위한 라디오파 가열기술 적용 연구는 현재까지 수행 된 바 없다.

따라서 본 연구는 $27.12 \mathrm{MHz}$ 라디오파와 열수 가열처리 가 절단 배추에 존재하는 호기성 세균, 효모 및 곰팡이, 대장균군과 유산균의 불활성에 미치는 영향과 미생물 생존 곡선을 설명할 수 있는 적합한 모델을 구명하고 가열처리한 배추의 절임 특성에 대한 기초 자료를 확보하고자 수행하였다.

\section{재료 및 방법}

\section{실험 재료}

본 실험에 사용한 배추(Brassica pekinensis L.) 시료는 2018년 7월 강원도 정선에서 수확한 ‘춘광' 품종을 광주 남구 소재 농수산물 도매시장에서 구입 후 겉잎과 비가식 부위를 제거하여 준비하였다. 1 차 정선한 배추 줄기 부위는 멸균 처리한 칼을 이용하여 가로 $4 \pm 0.5 \mathrm{~cm}$ 와 세로 $3 \pm 0.5$ $\mathrm{cm}$ 크기로 절단 후 배추의 가열 전처리와 염수 절임에 이용 하였다.

\section{라디오파 가열과 열수 처리}

라디오파와 열수 가열 처리를 위해 절단 배추 시료는 $300 \mathrm{~g}$ 을 칭량하여 멸균된 low-density polyethylene(LDPE) film bag에 각각 밀봉 포장 하였다. 라디오파 가열은 27.12 $\mathrm{MHz}$ 라디오파 가열 시스템(FRT-5, Yamamoto Vinita Corp., Ltd., Osaka, Japan)을 이용하여 시료와 상부 electrode의 간 격을 $40 \mathrm{~mm}$ 로 설정하고 1,000 과 $1,500 \mathrm{~W}$ 출력에서 시료를 각각 1,2 와 3 분 처리하였다. 열수 가열은 수온이 $60 \pm 1$ 과 $70 \pm 1^{\circ} \mathrm{C}$ 로 유지된 water bath(VS-1205SW1, Vision Scientific Corp., Bucheon, Korea)에 밀봉된 배추 시료를 각각 5,10 , 15 와 20 분 처리하였다. 가열 처리를 하지 않은 절단 배추를 대조구로 비교하였다.

\section{가열 처리에 따른 절단 배추의 미생물 수 변화 측정}

라디오파와 열수 가열 처리에 따른 절단 배추의 미생물 수 변화를 분석하기 위해 시료 $25 \mathrm{~g}$ 은 $0.85 \%$ 멸균 생리식염 수 $225 \mathrm{~mL}$ 가 담긴 멸균 필터 stomacher bag에 넣은 후 stomacher(Bagmixer R400, Interscience Inc., Saint Nom, France)를 이용해 3 분간 균질화 시켰다. 균질화 된 용액은 $0.85 \%$ 멸균 생리식염수로 10 배수 연속 희석한 후 희석액 $1 \mathrm{~mL}$ 를 각각의 배지에 분주하였다. 호기성 세균은 $3 \mathrm{M}$ Petrifilm ${ }^{\mathrm{TM}}$ aerobic count plate(Petrifilm AC, 3M Co., St. Paul, MN, USA)를 사용하여 $37^{\circ} \mathrm{C}$ 에서 48 시간 배양 후 붉은 집락수를 계수하였다. 효모 및 곰팡이는 $3 \mathrm{M}$ Petrifilm ${ }^{\mathrm{TM}}$ yeast and mold count plate(Petrifilm YM, 3M Co.)를 사용하 여 $25^{\circ} \mathrm{C}$ 에서 72 시간 배양 후 녹푸른색 집락수를 계수하였 다. 대장균군은 $3 \mathrm{M}$ Petrifilm ${ }^{\mathrm{TM}}$ coliform count plate(Petrifilm $\mathrm{CC}, 3 \mathrm{M} \mathrm{Co}$.)를 사용하여 $37^{\circ} \mathrm{C}$ 에서 24 시간 배양 후 기포가 생성된 붉은 집락수를 계수하였다. 유산균은 de Man, Rogosa and Sharpe agar(MRS, Difo, Detroit, MI, USA)를 사용하여 $37^{\circ} \mathrm{C}$ 에서 48 시간 혐기배양 후 노란 발색 반응을 나타낸 집락수를 계수하였다. 검출된 미생물 수는 시료 $\mathrm{g}$ 당 colony forming unit(CFU)로 나타냈고 3회 반복하여 측정하 였다. 
절단 배추의 미생물 불활성화 모델링

라디오파와 열수 가열 처리에 의한 절단 배추에 호기성 세균, 효모 및 곰팡이, 대장균군과 유산균 불활성은 first-order kinetic과 Weibull 모델을 각각 이용하여 설명하 였다. First-order kinetic 모델은 아래의 수식을 이용하였고 선형 inactivation curve에 유효하다(21).

$$
\log \frac{\mathrm{N}}{\mathrm{N}_{0}}=-\mathrm{KH}_{\mathrm{t}}
$$

$\mathrm{N}_{0}$ 은 시료의 초기 미생물 수, $\mathrm{N}$ 은 라디오파 가열 처리 후 시료의 미생물 수, $\mathrm{K}$ 는 1 차 반응 상수, $\mathrm{H}_{\mathrm{t}}$ 는 라디오파 또는 열수 가열 시간(분)을 각각 나타낸다. 한편 살균처리에 따른 microbial inactivation curve가 비선형을 나타날 때는 Weibull 모델이 적합하다(22). Weibull 모델은 아래의 수식 을 이용하였으며 $\alpha$ 와 $\beta$ 값은 Microsoft Excel 2015에 non-linear least-squares regression 해 찾기 기능을 이용하여 분석하였다.

$$
\log \frac{\mathrm{N}}{\mathrm{N}_{0}}=-\frac{1}{2.303}\left(\frac{\mathrm{H}_{\mathrm{t}}}{\mathrm{a}}\right)^{\beta}
$$

$a$ 는 characteristic 처리시간, $\beta$ 는 shape parameter이다. $D_{r}$ 은 미생물 수 $90 \%$ 감소에 필요한 가열처리 시간으로 아래 의 수식을 이용하여 분석하였다.

$$
\mathrm{D}_{\mathrm{r}}=\alpha \times(2.303)^{1 / \beta}
$$

가열 처리에 따른 절단 배추의 내부온도 time-temperature 와 표면온도 분포 변화 분석

절단 배추 시료의 중심부에 광섬유온도센서(FOTEMP4, Optocon AG, Dresden, Germany)를 삽입하고 라디오파와 열수 가열 중 처리 시간에 따른 온도 변화를 분석하였다. 라디오파와 열수 가열 처리 직후 절단 배추 표면온도 분포 는 적외선 카메라(A655SC, FLIR Systems, Stockholm, Sweden)를 이용하여 측정하였다. 시료의 표면온도 하강과 측정오류를 최소화하기 위해 시료의 온도 측정은 20 초 이 내로 완료하였다. 또한 표면온도 편차는 직사각형 시료 바 깥쪽으로부터 $1.5 \mathrm{~cm}$ 를 제외한 부분의 최고온도와 최저온 도 차이로 분석하였다.

절임 중 가열 처리한 절단 배추의 염도, 수분함량 및 경도 변화 분석

절단 배추의 절임을 위한 염수는 1 차 증류수에 정제염 (Hanju Corp., Ulsan, Korea)을 10\% 농도로 첨가하여 준비하 였다. 라디오파 또는 열수 가열 처리한 절단 배추는 $10 \%$ 염수가 담긴 $5 \mathrm{~L}$ 비커에 $1: 2(\mathrm{w} / \mathrm{v})$ 비율로 침지시키고 $15^{\circ} \mathrm{C}$ incubator에서 4시간 동안 절임을 실시하였다. 절임 중 절단 배추의 염도는 Mohr 적정법을 이용하여 분석하였다. 마쇄 한 배추 시료 $1 \mathrm{~g}$ 은 증류수로 50 배 희석하여 여과하였다. 여과액 $10 \mathrm{~mL}$ 에 지시약 $2 \%$ potassium chromate $1 \mathrm{~mL}$ 를 가한 뒤 $0.02 \mathrm{~N} \mathrm{AgNO}_{3}$ 용액으로 갈색이 되는 시점을 종말점 으로 적정하였다. $0.02 \mathrm{~N} \mathrm{AgNO}_{3}$ 용액의 소비량을 통해 염도(\%)를 계산하였다. 절단 배추의 수분함량은 시료 $1 \mathrm{~g}$ 을 aluminum weighting dish에 취한 후 적외선 수분측정기 (MB45, Ohaus Co., Pine Brook NJ, USA)를 이용하여 측정하 였다. 절단 배추의 경도는 texture analyzer(TA-XT2, Stable Micro System Ltd., Surrey, UK)를 사용하여 penetration test 를 행하였다. Choi 등(4)의 선행 연구 방법을 참고하여 지름 $2 \mathrm{~mm}$ cylindrical probe가 $0.5 \mathrm{~mm} / \mathrm{s}$ test speed와 $10 \mathrm{~mm}$ 깊이 로 배추 조직을 통과시킬 때 얻어지는 최대값을 측정하였 다. 측정 횟수는 각 처리구 당 절단 배추 조각을 무작위로 10 개 선발하여 반복 측정 후 평균값을 구하여 $\mathrm{kg}$ 으로 나타 내었다.

\section{통계처리}

모든 실험은 3회 이상 반복하여 측정하였으며 실험 결과 는 평균값 \pm 표준편차로 나타냈다. 처리평균 간의 유의성 검정은 SPSS(Statistical Package for the Social Science, Version 19, SPSS Inc., Chicago, IL, USA) program을 이용하 여 $p<0.05$ 수준에서 Duncan's multiple range test 방법으로 다중비교를 실시하였다.

\section{결과 및 고찰}

\section{라디오파와 열수 가열에 따른 절단 배추에 오염된 미생물} 불활성 효과

절임배추의 위생 상태와 품질에 가장 큰 영향을 미치는 인자는 절임배추에 생육하는 미생물 수이다(23). 1,000과 $1,500 \mathrm{~W}$ 라디오파 또는 60 과 $70^{\circ} \mathrm{C}$ 열수 가열처리에 따른 절단 배추에 호기성 세균, 효모 및 곰팡이, 대장균군과 유산 균의 생존곡선은 Fig. 1에 나타냈다. 본 연구에 사용한 배추 시료의 호기성 세균, 효모 및 곰팡이, 대장균군과 유산균의 분포는 2.55-5.29 $\log \mathrm{CFU} / \mathrm{g}$ 의 수준으로 나타났다(data not shown). Oh 등(24)은 국산 배추의 재배기간 중 배추잎 표면 에 Staphylococcus aureus와 B. cereus가 약 2.0-4.0 log CFU/g 수준으로 유지한 결과를 보고한 바 있다. 따라서 절임 전 배추 원료의 미생물 오염도를 낮출 있는 살균공정이 필요함 이 확인되었다.

$1,000 \mathrm{~W}$ 라디오파 3 분 처리는 절단 배추에 호기성 세균, 효모 및 곰팡이, 대장균군과 유산균 수를 각각 $1.88,1.04$, 4.36과 $2.62 \log \mathrm{CFU} / \mathrm{g}$ 감소시켰다. $1,500 \mathrm{~W}$ 라디오파의 경우, 3 분 처리 후 대장균군과 유산균 수는 각각 4.36 와 
(a)

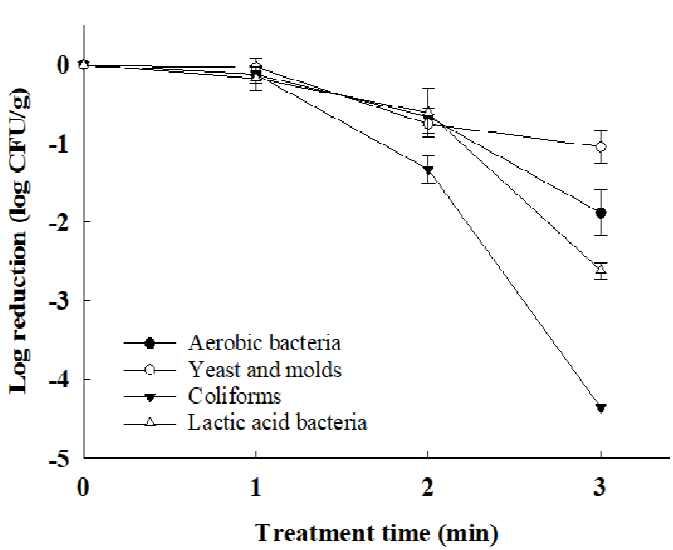

(c)

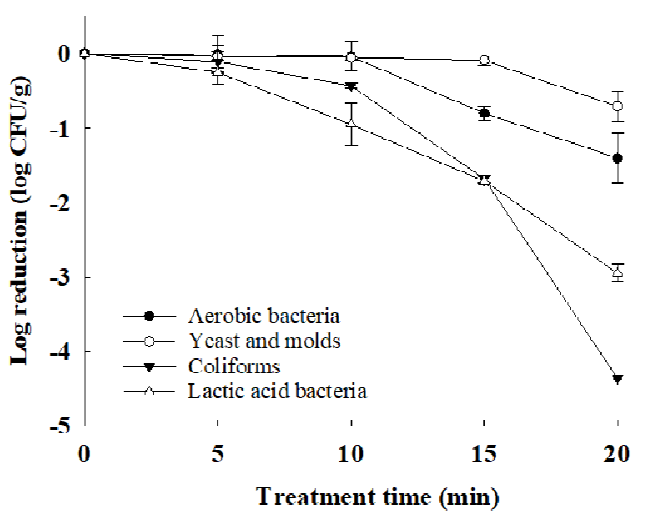

(b)

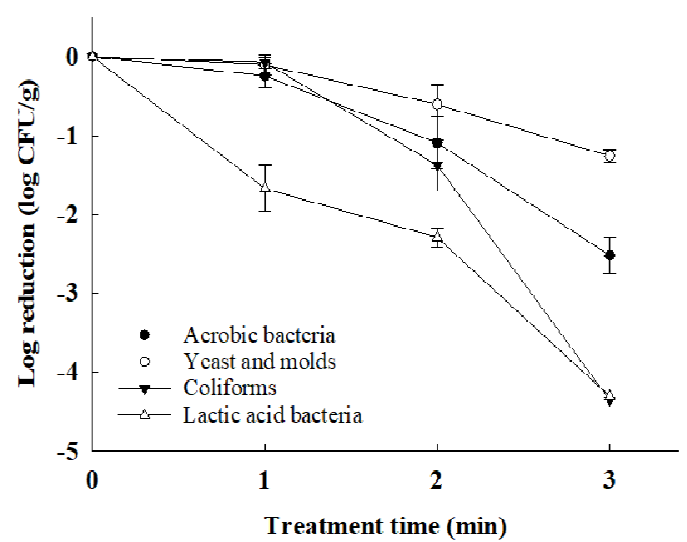

(d)



Fig. 1. Effect of radio frequency at 1,000 (a) and 1,500 W (b), and hot water heating at 60 (c) and $70^{\circ} \mathrm{C}$ (d) on the survival of pre-existing microor ganisms on shredded kimchi cabbages.

Each point represents the mean for triplicates and error bars show standard deviations.

$4.31 \log \mathrm{CFU} / \mathrm{g}$ 까지 감소하였다. 반면 60 과 $70^{\circ} \mathrm{C}$ 열수 5 분 처리는 절단 배추에 존재하는 호기성 세균, 효모 및 곰팡이, 대장균군, 유산균 수를 효과적으로 감소시키지 못했다. 특 히 호기성 세균은 60 과 $70^{\circ} \mathrm{C}$ 열수 10 분 처리까지 뚜렷한 감균효과를 보이지 않았다. 절단 배추에 대장균군과 유산 균 수는 $60^{\circ} \mathrm{C}$ 열수 20 분 처리로 각각 4.36 과 $2.95 \log \mathrm{CFU} / \mathrm{g}$ 까지 감소하였다. 또한 $70^{\circ} \mathrm{C}$ 열수 15 분 처리는 절단 배추에 대장균군과 유산균 수는 4.36과 $4.34 \log \mathrm{CFU} / \mathrm{g}$ 감소시켰으 며 이는 $1,500 \mathrm{~W}$ 라디오파 3 분 처리와 유사한 저해효과를 나타냈다. 이러한 결과는 절단 배추에 오염된 미생물 종류 에 따라 미생물의 일정한 수를 사멸시키는데 필요한 가열 온도와 처리 시간이 다름을 입증하였다. Orsat 등(25)은 $27.12 \mathrm{MHz}$ 라디오파 가열 2분 이내 처리로 진공 포장한 ready-to-eat 당근에 오염된 호기성 세균을 효과적으로 감소 시켰다고 보고하였는데 본 연구결과와 유사하였다. Lui 등 (26)도 $27.12 \mathrm{MHz}$ 라디오파 처리가 채심에 호기성 세균수 를 $3 \log \mathrm{CFU} / \mathrm{g}$ 이상 감소시킨 결과와 라디오파 가열 시스템 의 챔버 내 시료가 위치한 상부와 하부 electrode 간격과
처리 시간에 따라 살균 효과 차이가 있음을 보고하였다 따라서 $27.12 \mathrm{MH}$ 라디오파 유전가열은 열수 가열에 비해 절단 배추에 오염된 미생물 불활성에 소요되는 시간을 효과 적으로 절감할 수 있는 것으로 판단된다.

\section{절단 배추의 미생물 생존곡선 모델링}

라디오파와 열수 가열에 대한 절단 배추에 오염된 미생 물의 저해 감수성을 알아보기 위해 라디오파와 열수 가열 처리에 따른 미생물 생존 곡선 결과를 first-order kinetic 모델과 Weibull 모델에 각각 적용시키고 모델들의 적합성 을 확인하였다.

$1,000 \mathrm{~W}$ 라디오파 가열에 따른 호기성 세균, 효모 및 곰팡이, 대장균군과 유산균 수 변화에 대한 Weibull 모델의 root mean square error(RMSE) 값은 각각 $0,0.12,0.03$ 과 0.06 인 반면 first-order kinetic 모델의 RMSE 값은 $0.32,0.16$, 0.84 와 0.54 로 나타났다(Table 1). $1,500 \mathrm{~W}$ 라디오파 가열에 따른 호기성 세균, 효모 및 곰팡이, 대장균군과 유산균의 생존곡선도 Weibull 모델의 RMSE 값이 0.01-0.29로 
Table 1. Evaluation of two models estimating the reductions in pre-existing microorganisms on shredded kimchi cabbages after radio frequency heating at 1,000 and $1,500 \mathrm{~W}$, and after hot water heating at 60 and $70^{\circ} \mathrm{C}$

\begin{tabular}{|c|c|c|c|c|c|c|c|c|c|}
\hline \multirow[b]{2}{*}{ Microorganism } & \multirow[b]{2}{*}{ Model } & \multicolumn{4}{|c|}{ RMSE $^{1)}$} & \multicolumn{4}{|c|}{$\mathrm{R}^{2}$} \\
\hline & & $\begin{array}{c}1,000 \mathrm{~W} \text { radio } \\
\text { frequency }\end{array}$ & $\begin{array}{l}1,500 \mathrm{~W} \text { radio } \\
\text { frequency }\end{array}$ & $\begin{array}{c}60^{\circ} \mathrm{C} \\
\text { hot water }\end{array}$ & $\begin{array}{c}70^{\circ} \mathrm{C} \\
\text { hot water }\end{array}$ & $\begin{array}{l}1,000 \mathrm{~W} \text { radio } \\
\text { frequency }\end{array}$ & $\begin{array}{l}1,500 \mathrm{~W} \text { radio } \\
\text { frequency }\end{array}$ & $\begin{array}{l}60^{\circ} \mathrm{C} \text { hot } \\
\text { water }\end{array}$ & $\begin{array}{l}70^{\circ} \mathrm{C} \\
\text { hot water }\end{array}$ \\
\hline \multirow{2}{*}{ Aerobic bacteria } & First-order & 0.32 & 0.34 & 0.29 & 1.18 & 0.86 & 0.91 & 0.81 & 0.81 \\
\hline & Weibull & 0.00 & 0.01 & 0.10 & 0.36 & 1.00 & 1.00 & 0.97 & 0.91 \\
\hline \multirow{2}{*}{ Yeast and molds } & First-order & 0.16 & 0.17 & 0.18 & 1.49 & 0.90 & 0.92 & 0.60 & 0.82 \\
\hline & Weibull & 0.12 & 0.03 & 0.03 & 0.51 & 0.93 & 1.00 & 0.99 & 0.83 \\
\hline \multirow{2}{*}{ Coliforms } & First-order & 0.84 & 0.84 & 0.74 & 0.64 & 0.83 & 0.83 & 0.88 & 0.90 \\
\hline & Weibull & 0.03 & 0.06 & 0.72 & 0.63 & 1.00 & 1.00 & 0.88 & 0.90 \\
\hline \multirow{2}{*}{ Lactic acid bacteria } & First-order & 0.54 & 0.29 & 0.30 & 0.62 & 0.79 & 0.97 & 0.95 & 0.90 \\
\hline & Weibull & 0.06 & 0.29 & 0.05 & 0.61 & 1.00 & 0.97 & 1.00 & 0.90 \\
\hline
\end{tabular}

${ }^{11}$ Root mean square error

Table 2. Weibull model parameters for the inactivation of pre-existing microorganisms on the shredded kimchi cabbages after radio frequency and hot water heating

\begin{tabular}{ccccc}
\hline Heating treatment & Microorganism & $\mathrm{a}^{1)}$ & $\beta^{2)}$ & Dr-value \\
\hline & Aerobic bacteria & 1.70 & 2.56 & 2.35 \\
$1,000 \mathrm{~W}$ radio & Yeast and molds & 1.64 & 1.53 & 2.83 \\
frequency & Coliforms & 1.37 & 2.96 & 1.82 \\
& Lactic acid bacteria & 1.79 & 3.49 & 2.28 \\
\hline \multirow{3}{*}{$1,500 \mathrm{~W}$ radio } & Aerobic bacteria & 1.29 & 2.08 & 1.92 \\
frequency & Yeast and molds & 1.73 & 1.96 & 2.66 \\
& Coliforms & 1.36 & 2.92 & 1.81 \\
& Lactic acid bacteria & 0.33 & 1.02 & 0.75 \\
\hline \multirow{3}{*}{$60^{\circ} \mathrm{C}$ hot water } & Aerobic bacteria & 12.91 & 2.73 & 17.52 \\
& Yeast and molds & 18.63 & 7.01 & 20.99 \\
& Coliforms & 2.44 & 1.16 & 5.02 \\
& Lactic acid bacteria & 6.65 & 1.73 & 10.76 \\
\hline $70^{\circ} \mathrm{C}$ hot water & Aerobic bacteria & 8.58 & 2.25 & 12.42 \\
& Yeast and molds & 2.10 & 0.86 & 5.51 \\
& Coliforms & 2.17 & 1.09 & 4.66 \\
& Lactic acid bacteria & 2.29 & 1.12 & 4.83 \\
\hline
\end{tabular}

${ }^{1)}$ Characteristic time using radio frequency and hot water heating (min).

${ }^{2)}$ Shape parameter.

${ }^{3}$ Radio frequency and hot water heating time (s) required for $90 \%$ reduction of the counts of pre-existing microorganisms.

first-order kinetic 모델의 RMSE 값인 0.17-0.84와 비교하여 대부분 작게 나타났다. 또한 1,000 과 $1,500 \mathrm{~W}$ 라디오파 가열 처리한 절단 배추의 미생물 생존곡선에 적용된 Weibull 모델 correlation coefficients $\left(\mathrm{R}^{2}\right)$ 는 0.93-1.00으로 first-order kinetic 모델의 0.79-0.97과 비교하여 이상적인 1 에 가까운 값을 나타내었다. 따라서 1,000 과 $1,500 \mathrm{~W}$ 라디 오파 가열 처리를 이용한 절단 배추에 호기성 세균, 효모
및 곰팡이, 대장균군과 유산균 불활성화 모델은 비선형 Weibull 모델이 first-order kinetic 모델에 비해 높은 적합성 으로 나타냈다. 60 과 $70^{\circ} \mathrm{C}$ 열수 가열에 따른 호기성 세균, 효모 및 곰팡이, 대장균군과 유산균의 생존곡선도 firstorder kinetic 모델에 비해 Weibull 모델에서 낮은 RMSE 값과 높거나 같은 $\mathrm{R}^{2}$ 를 보여 비선형 모델이 더 적합하였다. $\mathrm{Hu}$ 등(27)은 $27.12 \mathrm{MHz}$ 라디오파 가열 처리에 따른 고춧가 루에 접종된 Salmonella typhimurium 생존곡선이 Weibull 모델에 높은 적합성을 나타냈다고 보고한 바 있다. 27.12 $\mathrm{MHz}$ 라디오파와 열풍을 병합한 가열 방법을 이용한 밤에 인위적으로 오염시킨 Penicillium crustosum, Penicillium discolor와 Penicillium expansum의 사멸곡선의 경우도 Weibull 모델이 first-order kinetic 모델에 비해 높은 $\mathrm{R}^{2}$ 값을 보인 결과가 보고되었다(28).

Weibull 모델의 $\alpha$ 와 $\beta$ 파라미터는 호기성 세균, 효모 및 곰팡이, 대장균군과 유산균의 생존 곡선 형태를 설명한다. Weibull 모델의 a 값은 스케일 파라미터로서 온도 의존성을 가지고 있으며 $a$ 파라미터 값의 대수는 온도와 선형적으로 관련된다(29). $1,500 \mathrm{~W}$ 라디오파 가열에 따른 호기성 세균, 효모 및 곰팡이, 대장균군과 유산균 수 변화 결과를 적용한 Weibull 모델의 a 값은 각각 $1.29,1.73,1.36$ 과 0.33 분으로 나타났다. 반면 $60^{\circ} \mathrm{C}$ 열수 가열에 따른 효모 및 곰팡이의 생존곡선을 적용한 Weibull 모델의 a 값은 18.63 분으로 가 장 큰 값을 보였다. $a$ 값의 변화는 미생물 생존 곡선의 기울 기를 변화시키지만 형태에는 영향을 미치지 않는다(27). 한편 1,000 과 $1,500 \mathrm{~W}$ 라디오파 가열에 따른 호기성 세 균, 효모 및 곰팡이, 대장균군과 유산균 생존곡선에 적용한 Weibull 모델의 $\beta$ 값은 1.02-3.49로 1보다 크기 때문에 아래 로 오목한 형태를 보인다. 또한 $1,500 \mathrm{~W}$ 라디오파 가열에 따른 호기성 세균, 효모 및 곰팡이와 대장균군과 유산균의 $\operatorname{Dr}$ 값은 각각 $1.92,2.66,1.81$ 과 0.75 분으로 나타났다. 따라 서 $1,500 \mathrm{~W}$ 라디오파 처리 3분 이내로 고춧가루에 존재하는 
미생물 $90 \%$ 이상 사멸이 가능하다고 판단된다.

$70^{\circ} \mathrm{C}$ 열수 가열의 효모 및 곰팡이 저해 결과를 적용한 Weibull 모델 $\beta$ 값은 0.86 으로 위로 볼록한 형태를 나타냈 다. 또한 60 과 $70^{\circ} \mathrm{C}$ 열수 가열에 따른 호기성 세균의 $\mathrm{D}_{\mathrm{r}}$ 값은 각각 17.52 와 12.42 분으로 $1,500 \mathrm{~W}$ 라디오파 가열의 $\mathrm{D}_{\mathrm{r}}$ 값 1.92 분과 비교하여 약 6.5 배 이상 차이를 보였다.

\section{가열 처리한 절단 배추의 절임 중 염도, 수분함량 및 경도 변화}

1,000 과 $1,500 \mathrm{~W}$ 라디오파(3분)와 60 과 $70^{\circ} \mathrm{C}$ 열수(20분) 가열 처리한 배추의 염수 절임 중 염도, 수분함량 및 경도 변화를 측정한 결과는 Table 3에 나타내었다.

배추의 염수 절임공정은 삼투작용으로 배추 조직 내에 $\mathrm{NaCl}$ 확산과 수분 유출이 동시에 발생하는데 절임배추의 일정 수준 이상의 염도는 부패미생물 생육을 억제한다 (30,31). 또한 절임배추의 염도는 소비자가 구매를 결정하 는데 중요한 지표이다. 라디오파 또는 열수 가열 처리는 절임 중 절단 배추의 염도 변화에 유의적인 $(\mathrm{p}<0.05)$ 영향을 미쳤다(Table 3). 절임 1 시간 후 1,000 과 $1,500 \mathrm{~W}$ 라디오파 처리한 절단 배추의 염도는 각각 3.02 와 $3.81 \%$ 로 대조구(가 열 처리하지 않은 절단 배추)의 $2.40 \%$ 와 유의적인 $(\mathrm{p}<0.05)$ 차이를 나타냈다. 또한 절임 4 시간 후 1,000 과 $1,500 \mathrm{~W}$ 라디오파와 60 과 $70^{\circ} \mathrm{C}$ 열수 처리한 절단배추의 염도는 4.00-4.77\%로 대조구에 비해 0.50-1.27\% 높은 값을 보였다. 따라서 절임 전 배추 원료의 라디오파 급속가열 전처리는배
추의 절임율을 높일 수 있을 것으로 판단된다.

1,000 과 $1,500 \mathrm{~W}$ 라디오파 3 분 처리 후 절단 배추의 수분 함량은 각각 94.14 와 $93.84 \%, 60$ 과 $70^{\circ} \mathrm{C}$ 열수 20 분 가열 처리한 절단 배추는 각각 93.43 과 $93.38 \%$ 로 나타나 대조구 의 초기 수분함량 $94.05 \%$ 와 유의적 $(\mathrm{p}<0.05)$ 차이를 보이지 않았다. 절임시간이 증가함에 따라 절단 배추의 수분함량 은 감소하는 경향을 나타냈다. 그러나 절임 4 시간 후 대조구 의 수분함량은 $89.50 \%$ 로 1,000 과 $1,500 \mathrm{~W}$ 라디오파와 60 과 $70^{\circ} \mathrm{C}$ 열수 처리구와 유의적 $(\mathrm{p}<0.05)$ 차이를 나타내지 않았다.

가열 처리한 절단 배추의 경도를 측정한 결과(Table 3 ), 1,000 과 $1,500 \mathrm{~W}$ 라디오파 및 60 과 $70^{\circ} \mathrm{C}$ 열수 처리한 절단 배추의 경도는 각각 $0.69,0.68,0.67$ 과 $0.72 \mathrm{~kg}$ 로 나타나 대조구에 비해 $0.12-0.17 \mathrm{~kg}$ 의 높은 값을 나타냈다. 저온 가열 처리는 펙틴질 세포벽 구조를 강화시키는 pectinesterase 활성을 유도하여 채소 조직의 경도를 증가시킨다(32). 한편 $80^{\circ} \mathrm{C}$ 이상의 고온에서 장시간 가열하면 배추의 세포막 파괴 와 세포 팽창으로 조직 손상 현상이 발생하지만 $60-70^{\circ} \mathrm{C}$ 저온 열처리는 갈변반응에 관여하는 효소활성 억제와 미생 물 감소시켜 저장 중 배추의 품질 변화를 방지할 수 있다 (33). 절임 4 시간 후 1,000 과 $1,500 \mathrm{~W}$ 라디오파 처리한 절단 배추의 경도는 $0.78 \mathrm{~kg}$ 이었으며 60 과 $70^{\circ} \mathrm{C}$ 열수 처리한 절 단 배추는 각각 0.72 와 $0.77 \mathrm{~kg}$ 으로 대조구와 비교하여 유의 적인 $(\mathrm{p}<0.05)$ 차이가 없었다. 따라서 라디오파 또는 열수 가열 처리가 절단 절임배추의 경도에 부정적인 영향이 없음

Table 3. Changes in salinity, moisture content, and hardness of shredded kimchi cabbages treated with radio frequency and hot water heating during salting

\begin{tabular}{|c|c|c|c|c|c|c|}
\hline \multirow{2}{*}{$\begin{array}{c}\text { Quality } \\
\text { parameter }\end{array}$} & \multirow{2}{*}{ Heating treatment } & \multicolumn{5}{|c|}{ Salting time (h) } \\
\hline & & 0 & 1 & 2 & 3 & 4 \\
\hline \multirow{5}{*}{ Salinity $(\%)$} & Control & $0.19 \pm 0.02^{1 \mathrm{C} e 2)}$ & $2.40 \pm 0.06^{\mathrm{Ed}}$ & $2.81 \pm 0.01^{\mathrm{Ec}}$ & $3.26 \pm 0.01^{\mathrm{Eb}}$ & $3.50 \pm 0.02^{\mathrm{Da}}$ \\
\hline & $1,000 \mathrm{~W}$ radio frequency & $0.22 \pm 0.01^{\mathrm{ABe}}$ & $3.02 \pm 0.11^{\mathrm{Ce}}$ & $3.94 \pm 0.02^{\mathrm{Cc}}$ & $4.41 \pm 0.14^{\mathrm{Bb}}$ & $4.73 \pm 0.04^{\mathrm{Aa}}$ \\
\hline & $1,500 \mathrm{~W}$ radio frequency & $0.23 \pm 0.01^{\mathrm{Ad}}$ & $3.81 \pm 0.13^{\mathrm{Ac}}$ & $4.53 \pm 0.06^{\mathrm{Ab}}$ & $4.59 \pm 0.07^{\mathrm{Ab}}$ & $4.77 \pm 0.05^{\mathrm{Aa}}$ \\
\hline & $60^{\circ} \mathrm{C}$ hot water & $0.20 \pm 0.02^{\mathrm{BCd}}$ & $2.80 \pm 0.15^{\mathrm{Dc}}$ & $3.36 \pm 0.08^{\mathrm{Db}}$ & $3.93 \pm 0.05^{\mathrm{Da}}$ & $4.00 \pm 0.06^{\mathrm{Ca}}$ \\
\hline & $70^{\circ} \mathrm{C}$ hot water & $0.22 \pm 0.01^{\mathrm{ABe}}$ & $3.35 \pm 0.01^{\mathrm{Bd}}$ & $4.12 \pm 0.01^{\mathrm{Bc}}$ & $4.22 \pm 0.11^{\mathrm{cb}}$ & $4.35 \pm 0.06^{\mathrm{Ba}}$ \\
\hline \multirow{5}{*}{ Moisture content (\%) } & Control & $94.05 \pm 0.39^{\mathrm{Aa}}$ & $91.06 \pm 0.52^{\mathrm{Ab}}$ & $90.95 \pm 0.35^{\mathrm{Ab}}$ & $90.28 \pm 0.81^{\mathrm{Abc}}$ & $89.50 \pm 0.52^{\mathrm{Ac}}$ \\
\hline & $1,000 \mathrm{~W}$ radio frequency & $94.14 \pm 0.89^{\mathrm{Aa}}$ & $91.50 \pm 0.79^{\mathrm{Ab}}$ & $90.23 \pm 0.66^{\mathrm{Abc}}$ & $90.21 \pm 0.71^{\mathrm{Abc}}$ & $89.77 \pm 0.73^{\mathrm{Ac}}$ \\
\hline & $1,500 \mathrm{~W}$ radio frequency & $93.84 \pm 0.63^{\mathrm{Aa}}$ & $91.91 \pm 0.64^{\mathrm{Ab}}$ & $90.92 \pm 0.67^{\mathrm{Ab}}$ & $90.86 \pm 0.24^{\mathrm{Ab}}$ & $90.76 \pm 1.02^{\mathrm{Ab}}$ \\
\hline & $60^{\circ} \mathrm{C}$ hot water & $93.43 \pm 0.72^{\mathrm{Aa}}$ & $91.07 \pm 0.41^{\mathrm{Ab}}$ & $90.91 \pm 0.23^{\mathrm{Ab}}$ & $90.75 \pm 0.54^{\mathrm{Ab}}$ & $90.20 \pm 0.16^{\mathrm{Ab}}$ \\
\hline & $70^{\circ} \mathrm{C}$ hot water & $93.38 \pm 1.09^{\mathrm{Aa}}$ & $90.91 \pm 0.45^{\mathrm{Ab}}$ & $90.96 \pm 0.38^{\mathrm{Ab}}$ & $90.89 \pm 1.01^{\mathrm{Ab}}$ & $90.84 \pm 1.03^{\mathrm{Ab}}$ \\
\hline \multirow{5}{*}{ Hardness (kg) } & Control & $0.55 \pm 0.05^{\mathrm{Bb}}$ & $0.69 \pm 0.09^{\mathrm{Aab}}$ & $0.66 \pm 0.07^{\mathrm{Aab}}$ & $0.65 \pm 0.07^{\mathrm{Aab}}$ & $0.76 \pm 0.11^{\text {Aa }}$ \\
\hline & $1,000 \mathrm{~W}$ radio frequency & $0.69 \pm 0.06^{\mathrm{Aa}}$ & $0.79 \pm 0.08^{\mathrm{Aa}}$ & $0.76 \pm 0.07^{\mathrm{Aa}}$ & $0.76 \pm 0.08^{\mathrm{Aa}}$ & $0.78 \pm 0.09^{\mathrm{Aa}}$ \\
\hline & $1,500 \mathrm{~W}$ radio frequency & $0.68 \pm 0.08^{\mathrm{Aa}}$ & $0.78 \pm 0.10^{\mathrm{Aa}}$ & $0.75 \pm 0.05^{\mathrm{Aa}}$ & $0.75 \pm 0.10^{\mathrm{Aa}}$ & $0.78 \pm 0.11^{\mathrm{Aa}}$ \\
\hline & $60^{\circ} \mathrm{C}$ hot water & $0.67 \pm 0.04^{\mathrm{Aa}}$ & $0.66 \pm 0.07^{\mathrm{Aa}}$ & $0.69 \pm 0.06^{\mathrm{Aa}}$ & $0.69 \pm 0.08^{\mathrm{Aa}}$ & $0.72 \pm 0.04^{\mathrm{Aa}}$ \\
\hline & $70^{\circ} \mathrm{C}$ hot water & $0.72 \pm 0.09^{\mathrm{Aa}}$ & $0.72 \pm 0.10^{\mathrm{Aa}}$ & $0.75 \pm 0.05^{\mathrm{Aa}}$ & $0.78 \pm 0.15^{\mathrm{Aa}}$ & $0.77 \pm 0.08^{\mathrm{Aa}}$ \\
\hline
\end{tabular}

\footnotetext{
${ }^{1)}$ Each value is mean $\pm \mathrm{SD}$
}

${ }^{2)}$ Mean values in the same column $\left({ }^{\mathrm{A}-\mathrm{E}}\right)$ or row $\left({ }^{\mathrm{a}-\mathrm{g}}\right)$ followed by different letters are significantly different according to Duncan's multiple range test $(\mathrm{p}<0.05)$. 
(a)
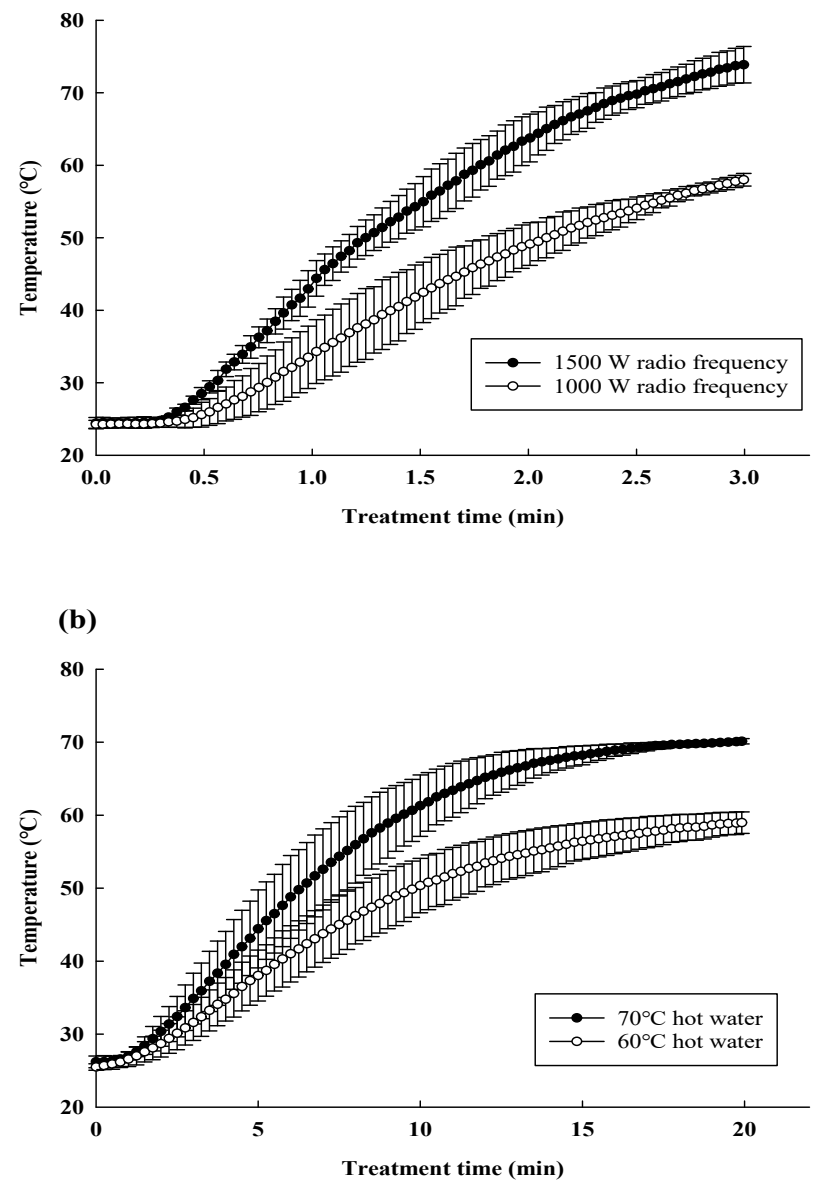

Fig. 2. Time-temperature profiles of shredded kimchi cabbage during radio frequency (a) and hot water (b) heating.
을 확인하였다.

가열 처리에 따른 절단 배추의 내부온도 time-temperature 와 표면온도 분포 변화

라디오파와 열수 가열 처리시간에 따른 절단 배추의 내 부온도 변화는 Fig. 2에 나타내었다. 1,000 과 $1,500 \mathrm{~W}$ 라디 오파 3 분 처리 후 절단 배추의 내부온도가 각각 58 과 $74^{\circ} \mathrm{C}$ 까 지 빠르게 증가하였다. 절단 배추의 내부온도가 $65^{\circ} \mathrm{C}$ 까지 도달하는데 $70^{\circ} \mathrm{C}$ 열수 처리는 11.88 분 소요된 반면 1,500 $\mathrm{W}$ 라디오파 처리는 2.08 분으로 가열 처리시간을 약 $1 / 6$ 배 수준으로 단축시킬 수 있었다. 본 연구결과 라디오파 유전 가열은 배추에 물분자가 전계 방향이 바뀔 때 발생시키는 마찰에너지를 열원으로 이용하기 때문에 열수에 의한 열전 도 방식보다 급속하게 온도를 상승시키는 것으로 판단된 다. Ozturk 등(34)에서 $27.12 \mathrm{MHz}$ 라디오 가열 시 옥수수 가루에 열전달속도는 $5.52^{\circ} \mathrm{C} / \mathrm{min}$ 으로 $85^{\circ} \mathrm{C}$ 열풍 가열의 $12.71^{\circ} \mathrm{C} / \mathrm{min}$ 보다 빠르다고 보고한 결과는 본 연구 결과와 유사하였다. 1,000 과 $1,500 \mathrm{~W}$ 라디오파와 60 과 $70^{\circ} \mathrm{C}$ 열수의 처리시간에 따른 절단 배추의 표면온도 분포 변화를 관찰한 결과는 Fig. 3 에 제시하였다. 1,000 과 $1,500 \mathrm{~W}$ 라디오파 3 분 가열 처리 후 절단 배추의 표면온도 편차는 각각 2.03 과 $2.37^{\circ} \mathrm{C}$ 로 균일한 분포를 나타냈다. 반면 60 과 $70^{\circ} \mathrm{C}$ 열수 20 분 가열 처리된 절단 배추의 표면온도 편차는 각각 4.77 과 $7.23^{\circ} \mathrm{C}$ 를 나타내 라디오파 가열 처리구에 비해 표면온도 분포가 불균일함을 확인하였다. (a)

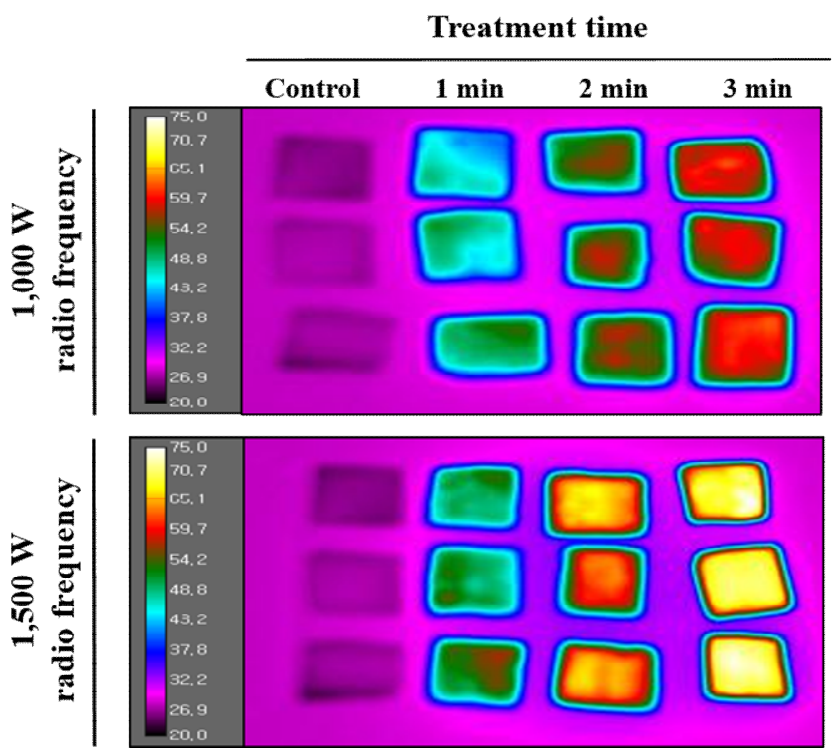

(b)



Fig. 3. The surface thermal distributions of shredded kimchi cabbage after radio frequency (a) and hot water (b) heating. 


\section{요 약}

본 연구는 $27.12 \mathrm{MHz}$ 라디오파와 열수 가열에 따른 절단 배추의 미생물 불활성화 효과를 모델링하고 절임 중 가열 처리된 절단 배추의 이화학적 품질 변화에 미치는 영향을 살펴보았다. $1,500 \mathrm{~W}$ 라디오파 3 분 가열은 절단배추에 호 기성 세균, 효모 및 곰팡이, 대장균군과 유산균 수를 각각 $2.56,1.26,4.36$ 과 4.31 까지 감소시켰다. 또한 라디오파와 열수 가열 처리에 따른 호기성 세균, 효모 및 곰팡이, 대장균 군과 유산균의 생존곡선은 Webull 모델에 높은 적합도를 나타냈다. 1,000 과 $1,500 \mathrm{~W}$ 라디오파 처리가 60 과 $70^{\circ} \mathrm{C}$ 열수 처리에 비해 절단 배추의 품온을 약 $60-70^{\circ} \mathrm{C}$ 까지 상승 시키는데 소요되는 시간이 적었으며 표면온도 분포도 균일 함을 관찰하였다. 한편 $10 \%$ 염수 절임 중 라디오파 또는 열수 가열 처리한 배추의 염도가 대조구에 비해 유의적으로 $(\mathrm{p}<0.05)$ 빠른 증가를 보였다. 염수 절임 후 라디오파 또는 열수 가열 처리한 배추와 대조구의 수분함량과 경도는 유의 적 차이가 없었다. 따라서 본 연구를 통해 절임배추 제조공 정에 라디오파 급속 및 균일가열을 이용한 배추 전처리 기술의 적용 가능성을 확인하였다. 향후 2 절 또는 4 절 형태 배추 원료의 라디오파 가열 전처리를 위한 라디오파 출력과 처리시간 최적화 연구가 필요할 것으로 사료된다.

\section{감사의 글}

본 연구는 세계김치연구소 기관고유사업(KE1803-4-1, KE1801-1)의 연구비 지원을 받아 수행되었으며, 이에 감사 드립니다.

\section{References}

1. Ha AW, Ju SY (2016) Nutrient intakes and frequently consumed foods among Korean adults according to the intake frequency of Baechu (Chinese cabbage) kimchi: Based on the 2012 2013 Korea national health and nutrition examination survey. J Nutr Health, 49, 125-133

2. Song HY, Cheon SH, Yoo SR, Chung YB, Seo HY (2016) Changes in quality characteristics of salted Kimchi cabbage and kimchi paste during storage. Korean J Food Preserv, 23, 459-470

3. Kim NH, Jang SH, Kim SH, Lee HJ, Kim Y, Ryu JH, Rhee MS (2015) Use of phytic acid and hyper-salting to eliminate Escherichia coli $\mathrm{O} 157: \mathrm{H} 7$ from napa cabbage for kimchi production in a commercial plant. Int J Food Microbiol, 214, 24-30
4. Choi EJ, Chung YB, Han AR, Chun HH (2015) Combined effects of sanitizer mixture and antimicrobial ice for improving microbial quality of salted Chinese cabbage during low temperature storage. J Korean Soc Food Sci Nutr, 44, 1715-1724

5. Kim HW, Jang JJ, Kim NH, Lee NY, Cho TJ, Kim SH, Rhee MS (2018) Factors that determine the microbiological quality of ready-to-use salted napa cabbage (Brassica pekinensis): Season and distribution temperature. Food Control, 87, 1-8

6. $\mathrm{Ku} \mathrm{KH}$, Choi EJ, Jeong MC (2014) Comparison of quality characteristics between seasonal cultivar of salted-Kimchi cabbage (Brassica rapa L. ssp. Pekinesis). Korean J Food Preserv, 21, 512-519

7. Lee KH (2008) Effect of ozone treatment for sanitation of Chinese cabbage and salted Chinese cabbage. J Korean Soc Food Sci Nutr, 37, 90-96

8. Park SS, Sung JM, Jeong JW, Park KJ, Lim JH (2013) Quality changes of salted Chinese cabbages with electrolyzed water washing and a low storage temperature. J Korean Soc Food Sci Nutr, 42, 615-620

9. Park SS, Sung JM, Jeong JW, Park KJ, Lim JH (2012) Efficacy of electrolyzed water and aqueous chlorine dioxide for reducing pathogenic microorganism on Chinese cabbage. Korean J Food Sci Technol, 44, 240-246

10. Gomez-Lopez VM, Lannoo AS, Gil MI, Allende A (2014) Minimum free chlorine residual level required for the inactivation of Escherichia coli $\mathrm{O} 157: \mathrm{H} 7$ and trihalomethane generation during dynamic washing of fresh-cut spinach. Food Control, 42, 132-138

11. Chhe C, Imaizumi T, Tanaka F, Uchino T (2018) Effects of hot-water blanching on the biological and physicochemical properties of sweet potato slices. Eng Agric Environ Food, 11, 19-24

12. Wang J, Yang XH, Mujumdar AS, Wang D, Zhao JH, Fang XM, Zhang Q, Xie L, Gao ZJ, Xiao HW (2017) Effects of various blanching methods on weight loss, enzymes inactivation, phytochemical contents, antioxidant capacity, ultrastructure and drying kinetics of red bell pepper (Capsicum annuum L.). LWT-Food Sci Technol, 77, 337-347

13. Rincon AM, Singh RK (2016) Inactivation of Shiga toxin-producing and nonpathogenic Escherichia coli in non-intact steaks cooked in a radio frequency oven. Food Control, 62, 390-396

14. Castro SM, Saraiva JA, Lopes-da-Silva JA, Delgadillo 
I, Van Loey A, Smout C, Hendrickx M (2008) Effect of thermal blanching and of high pressure treatments on sweet green and red bell pepper fruits (Capsicum annuum L.). Food Chem, 107, 1436-1449

15. Geveke DJ, Bigley AB, Brunkhorst CD (2017) Pasteurization of shell eggs using radio frequency heating. J Food Eng, 193, 53-57

16. Choi EJ, Yang HS, Park HW, Chun HH (2018) Inactivation of Escherichia coli O157:H7 and Staphylococcus aureus in red pepper powder using a combination of radio frequency thermal and indirect dielectric barrier discharge plasma non-thermal treatments. LWT-Food Sci Technol, 93, 477-484

17. Kou X, Li R, Hou L, Zhang L, Wang S (2018) Identifying possible non-thermal effects of radio frequency energy on inactivating food microorganisms. Int $\mathrm{J}$ Food Microbiol, 269, 89-97

18. Jeong SG, Baik OD, Kang DH (2017) Evaluation of radio-frequency heating in controlling Salmonella enterica in raw shelled almonds. Int J Food Microbiol, 254, 54-61

19. Jeong SG, Kang DH (2014) Influence of moisture content on inactivation of Escherichia coli $\mathrm{O} 157: \mathrm{H} 7$ and Salmonella enterica serovar Typhimurium in powdered red and black pepper spices by radio-frequency heating. Int J Food Microbiol, 176, 15-22

20. Kim SY, Sagong HG, Choi SH, Ryu S, Kang DH (2012) Radio-frequency heating to inactivate Salmonella Typhimurium and Escherichia coli O157:H7 on black and red pepper spice. Int J Food Microbiol, 153, 171-175

21. Chun HH, Kim HJ, Won M, Chung KS, Song KB (2010) A comparison of kinetic models of foodborne pathogen inactivation by aqueous chlorine dioxide, fumaric acid, and ultraviolet-C. J Korean Soc Appl Biol Chem, 53, 243-248

22. Bialka KL, Demirci A, Puri VM (2008) Modeling the inactivation of Escherichia coli O157:H7 and Salmonella enterica on raspberries and strawberries resulting from exposure to ozone or pulsed UV-light. J Food Eng, 85, 444-449

23. Kim JH, Park KY, Choi HS, Yang JY (2010) Quality evaluation of conventional salted cabbages. Korean J Food Nutr, 23, 659-663
24. Oh SY, Nam KW, Yoon DH (2017) Analysis of pathogenic microorganism's contamination and heavy metals on Kimchi cabbage by cultivation methods in Korea. J Food Hyg Saf, 32, 500-506

25. Orsat V, Gariepy Y, Raghavan GSV, Lyew D (2001) Radio-frequency treatment for ready-to-eat fresh carrots. Food Res Int, 34, 527-536

26. Liu Q, Zhang M, Xu B, Fang Z, Zheng D (2015) Effect of radio frequency heating on the sterilization and product quality of vacuum packaged Caixin. Food Bioprod Process, 95, 47-54

27. Hu S, Zhao Y, Hayouka Z, Wang D, Jiao S (2018) Inactivation kinetics for Salmonella typhimurium in red pepper powders treated by radio frequency heating. Food Control, 85, 437-442

28. Hou L, Kou X, Li R, Wang S (2018) Thermal inactivation of fungi in chestnuts by hot air assisted radio frequency treatments. Food Control, 93, 297-304

29. van Boekel MAJS (2002) On the use of the Weibull model to describe thermal inactivation of microbial vegetative cells. Int J Food Microbiol, 74, 139-159

30. Park SS, Sung JM, Jeong JW, Park KJ, Lim JH (2013) Quality changes of salted Chinese cabbages with electrolyzed water washing and a low storage temperature. J Korean Soc Food Sci Nutr, 42, 615-620

31. Han GJ, Son A, Lee SM, Jung JK, Kim SH, Park KY (2009) Improved quality and increased in vitro anticancer effect of kimchi by using natural sea salt without bittern and baked (Guwun) salt. J Korean Soc Food Sci Nutr, 38, 996-1002

32. Woo NRY, Chung HK, Kang MH (2005) Properties of Korean traditional pepper pickle made by different preheating temperature treatments. J Korean Soc Food Sci Nutr, 34, 1219-1225

33. Nugrahedi PY, Dekker M, Widianarko B, Verkerk R (2016) Quality of cabbage during long term steaming; phytochemical, texture and colour evaluation. LWT-Food Sci Technol, 65, 421-427

34. Ozturk S, Kong F, Singh, RK, Kuzy JD, Li C (2017) Radio frequency heating of corn flour: Heating rate and uniformity. Innovative Food Sci Emerging Technol, 44, 191-201 